\title{
Local Social Welfare and Selection of Residence
}

\section{OLE BERTELSEN}

It is the aim of this paper to point out some causes which could possibly be more determining for the internal migration in the years ahead.

This does not mean, that the causes for migration known today, such as job-seeking, education and housing, will not be main reasons, but perhaps will not be as dominating as now. From my point of view, the service offered by local political unities will have a growing importance on the population in their choice of residential municipality. The background for this is the growing amount of money collected by the government and municipalities in terms of taxes and duties, to maintain the social welfare state, which offers the population services, formerly taken care of by the families, for example day care institutions for the children and assistance to old people in their homes.

As the government has now "jammed on the brakes" as regard to public expenditures, the municipalities are faced with a quite different level of service and this will lead to a migration that possibly makes the age-segregation between the municipalities more accentuated compared to the situation today.

\section{Internal migration today}

The total number of internal immigrants in 1982 was 765,000 , which is 15 percent of the population. This number has been rather stable in the last decade, and the economic crises have had little influence, if any at all.

Inter-municipal migration amounted to 467,000 in 1982 . The principal migrators, almost 50 percent, are between 15 and 29 years old which is not surprising, since the young people move to areas with educational institutions; as much as $2 / 3$ of the girls obtain a vocational training today. The number of young people migrating in order to get a job is probably low, as the unemployment-rate is rather high in all parts of the country; especially among the $18-24$ year old. Another major cause for migration is the young people's acquirement of dwellings. During the phase of family-building, many couples would migrate in order to find suitable dwellings for the children. As an example, in Table 1 is shown how the number of children from a certain generation have moved from Copenhagen in the course of their first 5 years of life.

The period is the latter part of the seventies, in which vast building activities took place in satellite-municipalities of Copenhagen. As can be seen 30 percent of the children born in Copenhagen in 1975, were living elsewhere 5 years later. The impact of building activities on the age structure is shown in Table 2. Gentofte is a municipality north of Copenhagen which has had little building activity during the seventies, and in contrast Albertslund, west of Copenhagen, had a great building activity in the same period.

\section{The basis of future migration}

In order to grasp the future tendencies in migration, one has to go a further back to understand what has led to the present situation.

In many ways the economic boom, which had its beginning in the late $50 \mathrm{~s}$ paved the way for changes in many fields of the society.

Firstly, it gave job-possibilities for the women; the employment rate for women with small children has risen to circa 90 percent. 
$\mathrm{T}$ a $\mathrm{b} l \mathrm{e} 1$. Changes in the size of a generation in selected municipalities around Copenhagen. 1975-1980.

\begin{tabular}{|c|c|c|c|c|c|c|c|c|c|c|c|}
\hline & $1 / 1-75 \mathrm{~F}$ & $\begin{array}{l}\text { Reduc- } \\
\text { tion }\end{array}$ & $1 / 1-76$ & $\begin{array}{c}\text { Reduc- } \\
\text { tion }\end{array}$ & $-1 / 1-77$ & $\begin{array}{l}\text { Reduc- } \\
\text { tion }\end{array}$ & $-1 / 1-78$ & $\begin{array}{c}\text { Reduc- } \\
\text { tion }\end{array}$ & $1 / 1-79$ & $\begin{array}{l}\text { Reduc- } \\
\text { tion }\end{array}$ & $1 / 180$ \\
\hline & Number & r $\%$ & Number & r \% & Number & $\% 1$ & Number & r \% & Number & $\% \quad \mathrm{~N}$ & Number \\
\hline & $\begin{array}{l}\text { 0-year- } \\
\text { olds }\end{array}$ & & $\begin{array}{l}\text { 1-year- } \\
\text { olds }\end{array}$ & & $\begin{array}{l}\text { 2-year- } \\
\text { olds }\end{array}$ & & $\begin{array}{l}\text { 3-year- } \\
\text { olds }\end{array}$ & & $\begin{array}{l}\text { 4-year- } \\
\text { olds }\end{array}$ & & $\begin{array}{l}\text { 5-year- } \\
\text { olds }\end{array}$ \\
\hline København & 6.066 & 8.7 & 5.536 & 17.2 & 5.025 & 23.4 & 4.644 & 27.8 & 4.378 & 30.1 & 4.210 \\
\hline Frederiksberg & 963 & 4.6 & 920 & 15.7 & 812 & 20.5 & 766 & 26.0 & 713 & 29.3 & 681 \\
\hline Albertslund & 536 & +2.4 & 549 & +7.5 & 576 & +8.8 & 583 & +7.1 & 574 & +5.8 & 567 \\
\hline Gentofte & 593 & +1.3 & 601 & +1.7 & 603 & +3.7 & 615 & +3.9 & 616 & +8.4 & 643 \\
\hline Ishjøj & 353 & +13.9 & 402 & +18.1 & 417 & +24.1 & 438 & +26.9 & 448 & +23.8 & 437 \\
\hline \multirow[t]{2}{*}{ Brøndby } & 537 & +4.8 & 563 & +8.2 & 581 & +10.6 & 594 & +18.8 & 638 & +16.4 & 628 \\
\hline & & & $\begin{array}{l}\text { 0-year- } \\
\text { olds }\end{array}$ & & $\begin{array}{l}\text { 1-year- } \\
\text { olds }\end{array}$ & & $\begin{array}{l}\text { 2-year- } \\
\text { olds }\end{array}$ & & $\begin{array}{l}\text { 3-year- } \\
\text { olds }\end{array}$ & & $\begin{array}{l}\text { 4-year- } \\
\text { olds }\end{array}$ \\
\hline København & & & 5.892 & 10.8 & 5.254 & 18.5 & 4.800 & 23.5 & 4.507 & 26.3 & 4.342 \\
\hline Frederiksberg & & & 947 & 10.2 & 850 & 19.1 & 766 & 27.5 & 687 & 30.2 & 661 \\
\hline Albertslund & & & 534 & +9.2 & 583 & +14.0 & 609 & +12.2 & 599 & +9.0 & 582 \\
\hline Gentofte & & & 621 & +1.4 & 630 & +1.0 & 627 & +2.7 & 638 & +6.6 & 662 \\
\hline Ishøj & & & 434 & 0 & 434 & +3.2 & 448 & +9.7 & 476 & +7.4 & 466 \\
\hline \multirow[t]{2}{*}{ Brøndby } & & & 580 & +4.3 & 605 & +1.6 & 589 & +7.1 & 621 & +7.4 & 623 \\
\hline & & & & & $\begin{array}{l}\text { 0-year- } \\
\text { olds }\end{array}$ & & $\begin{array}{l}\text { 1-year- } \\
\text { olds }\end{array}$ & & $\begin{array}{l}\text { 2-year- } \\
\text { olds }\end{array}$ & & $\begin{array}{l}\text { 3-year- } \\
\text { olds }\end{array}$ \\
\hline København & & & & & 4.961 & 9.7 & 4.480 & 16.0 & 4.165 & 19.4 & 3.997 \\
\hline Frederiksberg & & & & & 792 & 9.2 & 719 & 14.0 & 681 & 17.4 & 654 \\
\hline Albertslund & & & & & 518 & 2.9 & 503 & +1.2 & 524 & +2.7 & 532 \\
\hline Gentofte & & & & & 573 & 1.0 & 567 & +0.5 & 576 & +0.1 & 576 \\
\hline Ishøj & 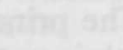 & & & & 423 & +6.6 & 451 & +8.7 & 460 & +4.7 & 443 \\
\hline \multirow[t]{2}{*}{ Brøndby } & . & 20 & & & 485 & 0.4 & 483 & +9.1 & 529 & +6.0 & 514 \\
\hline & & & & & & & $\begin{array}{l}\text { 0-year- } \\
\text { olds }\end{array}$ & & $\begin{array}{l}\text { 1-year- } \\
\text { olds }\end{array}$ & & $\begin{array}{l}\text { 2-year- } \\
\text { olds }\end{array}$ \\
\hline København & & & & & & & 4.583 & 9.6 & 4.145 & 14.9 & 3.899 \\
\hline Frederiksberg & & & & & & & 726 & 5.1 & 689 & 5.9 & 683 \\
\hline Albertslund & & & & & & & 484 & +3.1 & 499 & +4.1 & 504 \\
\hline Gentofte & & & & & & & 497 & +1.2 & 503 & +3.4 & 514 \\
\hline Gentofte & & & & & & & 497 & +1.2 & 503 & +3.4 & 514 \\
\hline Ishøj & & & & & & & 405 & +2.2 & 414 & 0 & 405 \\
\hline Brøndby & & & & & & & 532 & 11.5 & 593 & +7.5 & 572 \\
\hline
\end{tabular}

Secondly, new satellite cities were erected hand in hand with slum-clearance in the big cities around the country. The privately owned houses with gardens became a possibility for the majority of the population, especially if the woman also had a job. Public supported apartment houses were built in great number, but being a decision of the municipality as to whether to support the building of apartment houses, some municipalities refrained from doing so, or only on a small scale. This eventually led to sustenance or reinforcement of the differences in the income between the municipalities.

Thirdly, the road system was improved to make room for the growing number of privately owned cars and this facilitated the segregation of the residential areas from the working areas.

To summarize, three important features of the past two decades, namely the entrance of women into the labor force, now amounting to almost 90 percent of the age groups where children are born, the two-income families became able to 
$\mathrm{T}$ a b l e 2. The age structure in Gentofte and Albertslund municipalities 1978.

\begin{tabular}{|c|c|c|c|c|c|c|c|c|c|}
\hline \multicolumn{4}{|c|}{ Gentofte } & \multicolumn{3}{|c|}{ Whole country } & \multicolumn{3}{|c|}{ Albertslund } \\
\hline $0-4$ & 4.3 & \multirow{4}{*}{20.6} & \multirow{4}{*}{14.8} & 6.7 & \multirow{4}{*}{29.3} & \multirow{4}{*}{22.0} & \multirow{2}{*}{$\begin{array}{r}8.9 \\
10.8\end{array}$} & \multirow{4}{*}{39.5} & \multirow{4}{*}{31.4} \\
\hline $5-9$ & 4.8 & & & 7.2 & & & & & \\
\hline $10-14$ & 5.7 & & & 8.1 & & & 11.7 & & \\
\hline $15-19$ & 5.8 & & & 7.3 & & & 8.1 & & \\
\hline $20-24$ & 6.0 & & & 7.3 & . & 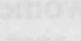 & 8.2 & & \\
\hline $25-29$ & 6.0 & & 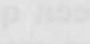 & 7.5 & & 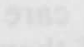 & 9.4 & & \\
\hline $30-34$ & 7.2 & 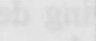 & & 8.2 & & 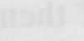 & 13.2 & & $\tan 2$ \\
\hline $35-39$ & 5.6 & & 62.0 & 6.3 & & 63.9 & 10.0 & & 66.5 \\
\hline $40-44$ & 4.9 & 56.2 & 109 & 5.6 & 56.6 & 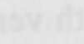 & 6.9 & 58.4 & $x$ \\
\hline $45-49$ & 5.1 & & & 5.4 & & & 4.5 & & trat \\
\hline $50-54$ & 6.3 & & & 5.6 & & & 2.8 & & \\
\hline $55-59$ & 7.7 & & & 5.6 & & & 2.1 & & \\
\hline $60-64$ & 7.4 & & & 5.1 & & & 1.3 & & a \\
\hline $65-69$ & 7.5 & & & 4.8 & & & 0.9 & & \\
\hline $70-74$ & 6.2 & & & 3.8 & & & 0.6 & & \\
\hline $75-79$ & 4.5 & & & 2.7 & & & 0.4 & 2.1 & \\
\hline $80-84$ & 2.9 & 28.0 & & 1.6 & 13.8 & & 0.1 & & \\
\hline $85-89$ & 1.4 & & & 0.7 & & & 0.1 & $\theta^{2}$ & \\
\hline $90-94$ & 0.4 & & & 0.2 & & & & $x^{2}=$ & \\
\hline $95-99$ & 0.1 & & $x^{2}$ & 0.0 & & & & 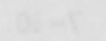 & \\
\hline 100 & 0.0 & & & 0.0 & & & & & \\
\hline & & 99.8 & & & & 99.7 & & & 100.0 \\
\hline
\end{tabular}

obtain the privately owned dwelling, and the building of houses, privately owned or rented was of such a magnitude that 25 percent of the population today live in houses built since 1970 . In the same period the number of cars was increased considerably which made it possible for the family to settle in areas segregated from the places of work.

\section{The public sector}

From the end of the 50 s and up till today the public sector has grown considerably. To build the welfare society the taxes and duties rose from 25 percent of the gross domestic product in the beginning of the 60 s to about 50 percent today. In all fields the services have been improved, medical care, higher education institutions, highway construction, day care institutions, old-age pensions, etc. And, of course, unemployment-relief has been a major item on the budget since the middle of the $70 \mathrm{~s}$.

To some degree and by the end of the period, the welfare society has been maintained by obtaining loans in foreign countries, and it has been said the "the Danes are heading for the bottomless pit, but still traveling first class.»

It is now the politics of the new conservative/liberal government to reorganize the public services in order to obtain balance on the budget.

The idea of reorganizing/readjustment contains two elements. On the one hand services that are without charges should be paid for and prizes for those already paid for should be raised. On the other hand public services should, if possible, be carried over to private enterprises or should be taken care of by private persons, a kind of de-professionalism. 


\section{Day care institutions}

As an example of a public service, which might become very determining for internal migration, especially in the light of the tightening of public expenditures, I will point at day care institutions for children.

Erecting and running the day care institutions is assigned to the single municipality that according to the law has to provide the "necessary" number of places to the community. From 1966 and up till today the number of places have expanded considerably, from 50,000 to 260,000 . This, of course, followed the rise in employment-rate for women with small children.

The demand for day care institutions has been quite different between the municipalities, but all of them has experienced a growing demand.

Now, as there is almost a stop for establishing more day care institutions, the municipalities are left with very different levels of coverage, as can be seen from Table 3.

$\mathrm{T}$ a b l e 3. Highest and lowest coverage with day care for children between $0-10$ years of age in municipalities 1983 .

\begin{tabular}{cccc}
\hline Age group & Highest coverage & All Denmark & Lowest coverage \\
\hline $0-2$ & 72,8 & 40,8 & 13,1 \\
$3-6$ & 85,8 & 56,2 & 22,1 \\
$7-10$ & 55,3 & 17,8 & 0 \\
\hline
\end{tabular}

A few municipalities will have to reduce the number of places on account of the falling birth rate, other municipalities still have a shortage of places in order to cover the actual demand.

But, as will be seen from Figure 1, there is still a very large gap between the number of children and the number of places, the country taken as a whole. The figure also shows the future number of children, according to the latest prognosis and the number of places according to the plans of the municipalities. Full coverage would be obtained if the number of birth falls to about 35,000 whereas the figure is now 50,000 .

\section{The demand for day care and migration}

The development in fertility for the past 15-20 years shows a reduced birth rate in all age groups, fewer births of higher order and a somewhat higher average age at childbearing. This can be interpreted as a resitation to have children in reply to the often very difficult situation of families with small children.

The decision to have children has to be taken in view of the woman's job-situation; will childbearing hinter the woman in maintaining her job, in view of the possibilities of finding a suitable dwelling, and in view of possibilities of obtaining day-care for the child.

First of all the women do stay in the labor market after giving birth. Among the young women the employment rate is higher for women with small children than for women without children. This is most probably due to the high expenditures in connection with establishing the family dwelling.

Secondly, what are the possibilities for getting day care for the child? Investigations from 1975 shows that the children are taken care of either in day care institutions or in private homes. Day care in private homes is either 
$\mathrm{Fi}$ g u r e 1. The number of children aged $0-10$ years and the number of places in day care institutions, 1966-1984, and prognosis.

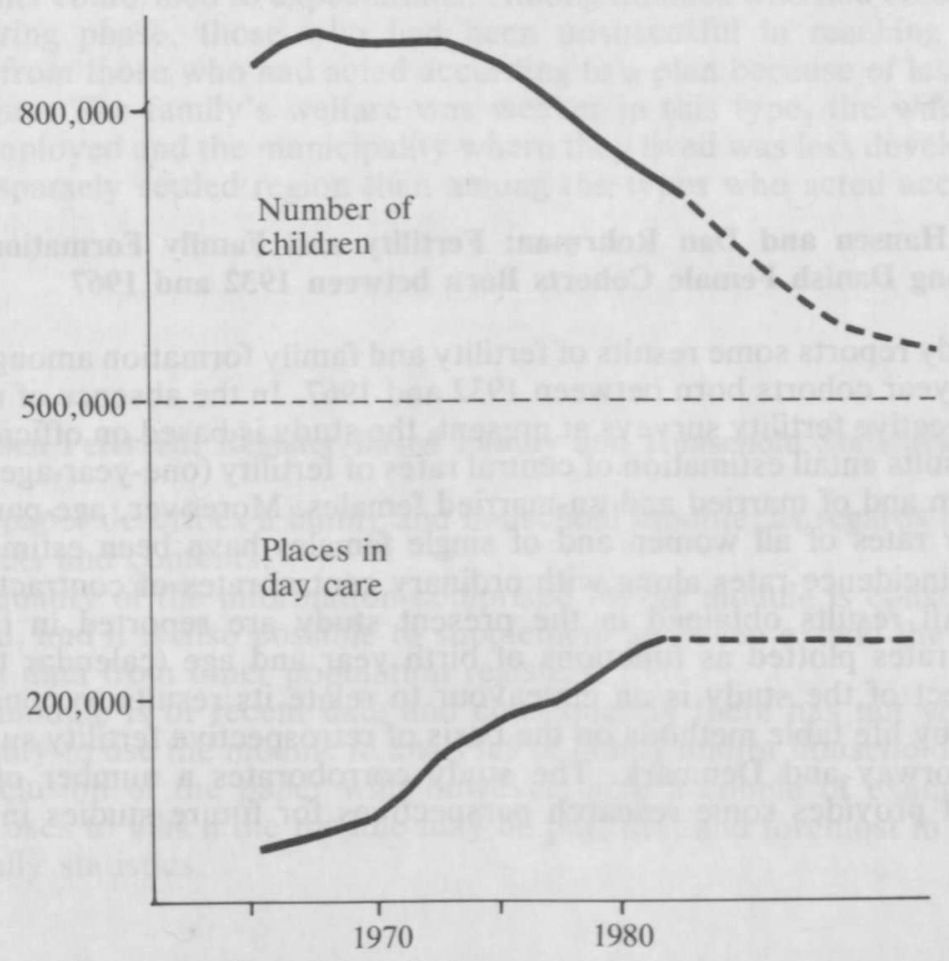

public supported and supervised or privately arranged »black market» arrangements. Grandmothers are used in very small scale, partly due to the fact that they themselves have jobs and that they are far away from their grand-children. Young girls employed in the home to take care of the children is also used in small scale. This might be due to the girls' preference for a formal education which might be obtained in educational institutions.

Families then are left with two possibilities, day care institutions run by the municipalities or private arrangements. Now as the employment rate for women is very high and still is showing an upwards tendency, private arrangements might become of declining importance in the years to come. From this follows that the municipalities will experience a growing demand for day care at at time when establishing new places are very scarce on account of the economics.

The outcome of this situation might be that young couples settle in municipalities which have relatively high coverage. A preliminary investigation in the 32 municipalities of Fyn seems to support this. Communities with rather high coverage of public day care have experienced less decline in the number of children; the falling birth-rate has brought about a decline in number of children in all municipalities. But it is only, as mentioned, a preliminary investigation, and further research has to be made.

\section{Concluding remarks}

By this paper I have tried to point at the public services as the incentive in internal migration of young couples with small children.

This view might be extended to include other groups of the society, the result of which will be a strengthening of the age segregation between the municipalities. 